\title{
Historical anthropogenic heavy metal input to the south-eastern North Sea
}

\author{
Florian Boxberg ${ }^{1} \cdot$ Sanja Asendorf ${ }^{1} \cdot$ Alexander Bartholomä ${ }^{2} \cdot$ Bernhard Schnetger $^{3} \cdot$ Willem P. de Lange $^{4}$. \\ Dierk Hebbeln ${ }^{1}$
}

Received: 11 February 2019 / Accepted: 26 August 2019 / Published online: 9 September 2019

(C) The Author(s) 2019

\begin{abstract}
The Helgoland Mud Area (HMA) in the German Bight, covering an area of approximately $500 \mathrm{~km}^{2}$, is one of a few depocentres for finer sediments in the North Sea. Radiocarbon and ${ }^{210} \mathrm{~Pb}$ analyses revealed continuous sedimentation over the last several centuries. Zinc $(\mathrm{Zn})$ and lead $(\mathrm{Pb})$ contents in the sediments show a distinct increase towards the youngest most sediments with the thickness of the heavy metal enriched sediments ranging from 15 to $103 \mathrm{~cm}$. Stratigraphic data indicate that the onset of heavy metal enrichment is diachronous progressing north-westward over the depocentre, paralleled by a decrease in the thickness of the enriched layer. Beginning already during medieval times, the enhanced input of $\mathrm{Zn}$ and $\mathrm{Pb}$ seemingly is related to silver and zinc mining in the Harz Mountains and the Erzgebirge, well-known mining areas since the Bronze Age. Both regions are directly connected to the HMA by the Elbe and Weser rivers. $\mathrm{Zn}$ and $\mathrm{Pb}$ enrichment began in the south-eastern HMA and progressed subsequently with an average of $10 \mathrm{~m}$ per year north-westward, most likely triggered by variations in river discharge and by the hydrodynamic setting. Quantitative assessments of the $\mathrm{Zn}$ and $\mathrm{Pb}$ content in the sediments suggest that since the onset of enhanced $\mathrm{Zn}$ and $\mathrm{Pb}$ deposition, the anthropic $\mathrm{Zn}$ and $\mathrm{Pb}$ input in the HMA amounts to $\sim 12,000 \mathrm{t}$ and $\sim 4000 \mathrm{t}$, respectively.
\end{abstract}

\section{Introduction}

The southern North Sea with its mesotidal and high waveenergy levels is generally characterised by sediment redistribution as the dominating sedimentological process. Only a few depocentres for the deposition of finer sediments exist in the North Sea (Lohse et al. 1995). One is the Helgoland Mud Area (HMA) in the German Bight in the SE North Sea (Fig. 1). In its centre, up to $30 \mathrm{~m}$ of sediments of Holocene age have accumulated (von Haugwitz et al. 1988). Despite generally low water depths of $\sim 30 \mathrm{~m}$ in the west and $\sim 15 \mathrm{~m}$ in the east (Fig. 1), a spatially coherent sedimentation pattern (Irion et al. 1987; Hebbeln et al. 2003) as well as the presence of

Dierk Hebbeln

dhebbeln@marum.de

1 MARUM — Centre for Marine Environmental Sciences, University of Bremen, Bremen, Germany

2 Marine Sedimentology Research Department, Senckenberg am Meer, Wilhelmshaven, Germany

3 Institut für Chemie und Biologie des Meeres (ICBM), Carl von Ossietzky Universität, Oldenburg, Germany

4 School of Science, University of Waikato, Hamilton, New Zealand undisturbed palaeo-records (e.g. Scheurle et al. 2005) demonstrate the long-term depositional nature of the HMA. This also holds true for the most recent times, when human activities contributed substantially to sediment redistribution in the German Bight (Rijnsdorp et al. 1998; OSPAR Commission 2000), as a high-resolution paleo-record from the HMA can be well correlated to the 120-year-long instrumental Helgoland Roads time series (Scheurle and Hebbeln 2003).

Förstner and Reineck (1974) were the first to describe an increase in the content of heavy metals in the uppermost decimetres of the sediments of the HMA. Based on ${ }^{210} \mathrm{~Pb}$ and ${ }^{137} \mathrm{Cs}$ dating, Dominik et al. (1978) estimated that the increased input of these heavy metals (including $\mathrm{Zn}$ and $\mathrm{Pb}$ ) started in the second half of the nineteenth century, with a second marked increase between AD 1930 and 1950. Analysing a set of 21 sediment cores, Irion et al. (1987) showed the presence of a distinct spatial pattern within this depocentre, marked by increasing thicknesses of $\mathrm{Zn}$-enriched layers from a few centimetres in the west to $>300 \mathrm{~cm}$ in the east. Without having any detailed stratigraphic data, Irion et al. (1987) assumed that the increased $\mathrm{Zn}$ input only began in post-war times due to the dumping of contaminated harbour and estuarine muds. However, their interpretation yielded sedimentation rates for the uppermost sediments of the HMA of 
Fig. 1 Location, extent and thickness (m) of the Helgoland Mud Area (shaded area and bold dashed lines (after von Haugwitz et al. 1988)) to the southeast of the Island of Helgoland in the German Bight, SE North Sea (see inset map). The red dots mark the locations of the investigated sediment cores (modified from Hebbeln et al. 2003). Inset map shows the location of the Helgoland Mud Area and the catchments of the Elbe and Weser. $\mathrm{X}$ marks the location of the Eiderstedt Peninsula, 1 and 2 mark the Harz Mountains and the Erzgebirge, respectively

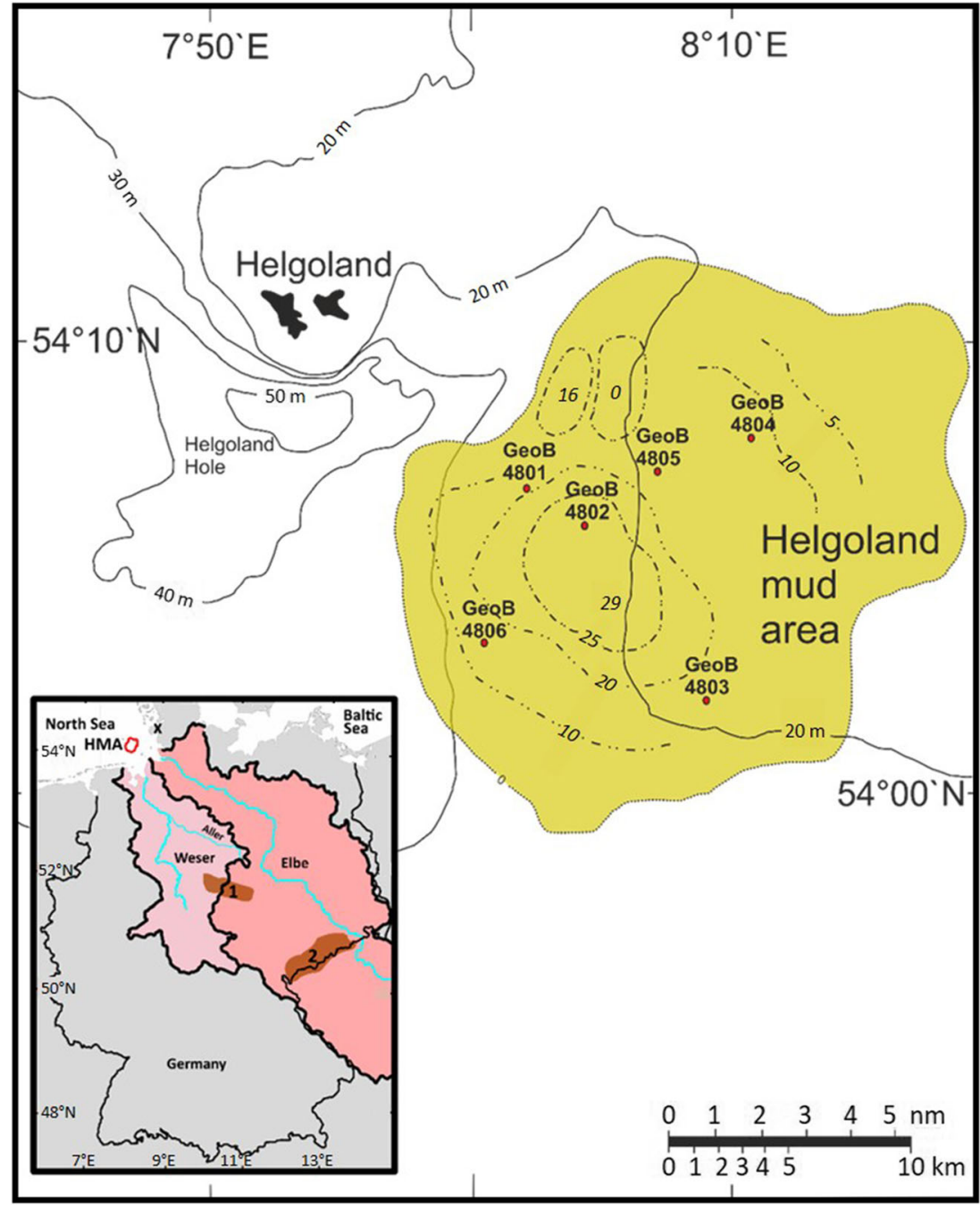

$>30 \mathrm{~mm} \mathrm{year}^{-1}$, which are much higher than estimates of $2 \mathrm{~mm}$ year $^{-1}$ based on sedimentological observations (Reineck 1963), $7.7 \mathrm{~mm}$ year ${ }^{-1}$ based on ${ }^{210} \mathrm{~Pb}$ and ${ }^{137} \mathrm{Cs}$ dating (Dominik et al. 1978), and 1.6 to $3 \mathrm{~mm}_{\text {year }}{ }^{-1}$ based on radiocarbon dating (Hebbeln et al. 2003; Serna et al. 2010).

Based on the analysis of sediment core GeoB 4801-1 from the HMA, Hebbeln et al. (2003) showed an onset of the $\mathrm{Zn}$ increase as early as AD 1750 (corrected here to AD 1850, see below). This early onset was linked to silver and zinc mining activities in the Harz Mountains and the Erzgebirge. Both are well-known mining areas located along the tributaries of the Elbe and Weser rivers that both drain into the German Bight. Near these mining areas and along the rivers, silver and zinc mining left traces in the environment since medieval times (e.g. Bartels 1996; Matschullat et al. 1997; Ortlam 1989).

There is agreement that the heavy metal enrichment in the uppermost sediments of the HMA is based on human activities (Förstner and Reineck 1974; Dominik et al. 1978; Irion et al. 1987; Hebbeln et al. 2003). Such pollution can cause severe problems. A mobilisation of heavy metals, such as $\mathrm{Zn}$ and $\mathrm{Pb}$, from the sediments in marine environments could endanger marine organisms and consequently negatively influence the marine food chain (Förstner and Müller 1973). Indeed, Rotstigen (2009) showed that both the absolute abundance and the diversity of benthic foraminifera in the HMA has decreased dramatically since the beginning $\sim \mathrm{AD} 1800$, coinciding with an increase in abnormal foraminifera morphologies.

Although the available data draw a coherent picture of (south-)eastward increasing thicknesses of the $\mathrm{Zn}$ - and $\mathrm{Pb}$ enriched layer in the HMA, the temporal development of anthropogenic induced $\mathrm{Zn}$ and $\mathrm{Pb}$ inputs is uncertain. As the onset of enhanced heavy metal input to the HMA in the mid-twentieth century (Irion et al. 1987) has been challenged by radiocarbon-based data documenting a much earlier onset (Hebbeln et al. 2003) and as the so far favoured interpretation of a temporally coherent onset over the entire HMA (Irion et al. 1987) would require drastic variations in sedimentation rates, the temporal development of enhanced $\mathrm{Zn}$ and $\mathrm{Pb}$ inputs to the HMA requires a critical evaluation. Therefore, based on 
a set of five new dated sediment cores, this study aims to analyse the spatio-temporal development of anthropogenic $\mathrm{Zn}$ and $\mathrm{Pb}$ input to the HMA, to identify possible sources and to understand the transport and deposition of heavy metals (and sediments).

\section{Regional setting}

The sediment transport mechanisms in the southern North Sea are dominated by the bedload transport of mobile sands and by the suspended load of fine particles supplied by several rivers, however, with the latter being largely exported from the region due to relatively high hydrodynamic energy levels (e.g. Puls et al. 1997; Zeiler et al. 2000). The HMA is the only significant depocentre for fine sediments in the southern North Sea, except from some intertidal flats and some estuaries (Figge 1981). However, its evolution is still under discussion. The following theory for the evolution of the HMA is based on the studies of Hertweck (1983), von Haugwitz et al. (1988) and Mayer (1995). When sea level rose and erosive wave action resulted in the disconnection between Eiderstedt Peninsula and the island of Helgoland between 1500 years (von Haugwitz et al. 1988) and 2000-3000 years ago (Irion et al. 1987), the modern-day circulation in the SE North Sea with longshore currents from $\mathrm{W}$ to $\mathrm{E}$ and from $\mathrm{S}$ to $\mathrm{N}$ was established. This has been assumed as the main trigger for the onset of the deposition of suspended particulate matter (SPM) in the HMA (Reineck et al. 1967).

The continuous deposition of finer sediments in the HMA is attributed to a small-scale, anti-clockwise eddy that is driven by the interactions of longshore coastal currents, the discharge from the Elbe and Weser rivers, and tidal dynamics (Hertweck 1983). This eddy can be subdivided into five small-scale eddies, one of them being the main driver for the deposition of fine sediments in the HMA (Mayer 1995). A three-dimensional, numerical model for the transport of SPM revealed the existence of vertical eddies with the rising side situated above the HMA that appear to be consistent at nearly every wind direction (Mayer 1995). This leads to a net accumulation of the fine suspended matter as the settling fine particles cannot be transported out of the eddy due to the low horizontal velocities (Mayer 1995).

Presently, the HMA covers an area of approximately $500 \mathrm{~km}^{2}$ with a mean water depth of $\sim 20 \mathrm{~m}$ (Fig. 1). The sea bottom rises from $\mathrm{W}$ to $\mathrm{E}$ with the western part mainly being composed of muddy sediments with an increasing amount of sand in the sediments towards the eastern part (Hertweck 1983).

\section{Methods}

A set of six gravity cores with lengths between $6.87 \mathrm{~m}$ and $11.41 \mathrm{~m}$ was collected from the HMA during RV Meteor cruise M 40/0 in 1997 (Table 1) in close proximity to each other (Fig. 1). The sediment cores were split lengthwise into two halves. One half was analysed for the chemical composition of the sediments using an XRF Core Scanner III (AVAATECH Serial No. 12) at MARUM, University of Bremen. This instrument allowed for a non-destructive, semi-quantitative determination of major and minor elements (e.g. heavy metals). In this study, only $\mathrm{Zn}$ and $\mathrm{Pb}$ contents will be discussed. The other half was used to take discrete samples for the quantitative analysis of $\mathrm{Zn}$ and $\mathrm{Pb}$ contents and to determine the age of the sediment at selected depth levels.

For XRF scanning, the split core surface was covered with a 4- $\mu \mathrm{m}$ thin SPEXCerti Prep Ultralene 1 foil to avoid contamination of the XRF measurement unit and desiccation of the sediment. Net intensities of $\mathrm{Zn}$ and $\mathrm{Pb}$ were measured at $1-\mathrm{cm}$ intervals for the upper two core sections for each core. Further downcore, the scanning interval was increased to $2 \mathrm{~cm}$. Measurements were conducted over a $1-\mathrm{cm}^{2}$ area with a down-core split size of $10 \mathrm{~mm}$ using generator settings of (1) $30 \mathrm{kV}$, a current of $1.0 \mathrm{~mA}$, and (2) $10 \mathrm{kV}$, a current of $0.3 \mathrm{~mA}$, both with a sampling time of $20 \mathrm{~s}$ directly at the split core surface. Data were acquired using a Canberra Digital Spectrum Analyser DAS 1000 and an Oxford Instruments 100W Neptune X-ray tube with Rhodium (Rh) target material. The raw data spectra were processed by the analysis of X-ray spectra by applying the Iterative Least Square software (WIN AXIL) package from Canberra Eurisys. The resulting data were provided for every measured element in counts per $20 \mathrm{~s}$ and the $\mathrm{Zn}$ and $\mathrm{Pb}$ data being focused on here are provided as normalised net intensities, i.e. as percentages of the total counts for each individual measurement, to minimise errors due to variable water content, grain size variations and others (Tjallingii et al. 2007). For analysing marine sediment cores, XRF scanning has become increasingly popular in the past decades because it allows non-destructive extraction of near-continuous records of element intensities from sediment cores with a minimum of analytical effort with the results being seen as valuable indicators for true element concentrations (e.g. Weltje and Tjallingii 2008).

To calibrate the XRF scanner data for $\mathrm{Zn}$ and $\mathrm{Pb}, 66$ discrete samples of $10 \mathrm{~cm}^{3}$, taken at positions corresponding to the core-scanner measurements, were taken, freeze dried and grounded using a mortar and pestle. Then $700 \pm 0.6 \mathrm{mg}$ of each sample was weighed into a ceramic crucible and mixed with $4200 \pm 1 \mathrm{mg}$ of a di-lithium tetraborate fusion flux (Spectromelt ${ }^{\circ}$ A10; Merck) and about $1000 \mathrm{mg}$ of ammonium nitrate. After $1 \mathrm{~h}$ of pre-annealing at $500^{\circ} \mathrm{C}$, the samples were fused and transformed into glass beads and measured for the $\mathrm{Zn}$ and $\mathrm{Pb}$ contents via wavelength dispersive XRF spectrometry (WD-XRF) at ICBM, University of Oldenburg. To determine the trueness and precision of the method, an international reference material (GSR 6) and in-house standards (Peru-1, Loess 1.6) were used. The results for the three 
Table 1 Site information for the sediment cores collected from the Helgoland Mud Area taken by the German RV Meteor during cruise M40/0 in 1997

\begin{tabular}{llllc}
\hline Core number & Latitude & Longitude & Water depth (m) & Core length (m) \\
\hline GeoB 4801-1 & $54^{\circ} 06.7^{\prime} \mathrm{N}$ & $8^{\circ} 02.2^{\prime} \mathrm{E}$ & 25 & 11.41 \\
GeoB 4802-1 & $54^{\circ} 05.7^{\prime} \mathrm{N}$ & $8^{\circ} 04.4^{\prime} \mathrm{E}$ & 25 & 8.01 \\
GeoB 4803-1 & $54^{\circ} 01.7^{\prime} \mathrm{N}$ & $8^{\circ} 09.0^{\prime} \mathrm{E}$ & 22 & 7.25 \\
GeoB 4804-1 & $54^{\circ} 07.8^{\prime} \mathrm{N}$ & $8^{\circ} 10.8^{\prime} \mathrm{E}$ & 20 & 6.87 \\
GeoB 4805-1 & $54^{\circ} 06.8^{\prime} \mathrm{N}$ & $8^{\circ} 07.6^{\prime} \mathrm{E}$ & 21 & 7.34 \\
GeoB 4806-1 & $54^{\circ} 03.1^{\prime} \mathrm{N}$ & $8^{\circ} 00.6^{\prime} \mathrm{E}$ & 29 & 7.40 \\
\hline
\end{tabular}

different reference materials used as standards matched the contents given in the literature or expected values. The normalised net intensities (or relative contents) were converted to absolute element contents using linear regressions between XRF scanner-derived relative contents and absolute element contents measured on the corresponding 66 discrete samples measured quantitatively (e.g. Jansen et al. 1998; Kido et al. 2006; Tjallingii et al. 2007).

To put the historic development of $\mathrm{Zn}$ and $\mathrm{Pb}$ contents in the HMA in a stratigraphic framework, discrete samples from different depths were taken for accelerator mass spectrometer radiocarbon (AMS ${ }^{14} \mathrm{C}$ ) dating. Samples were wet-sieved over 500,150 and $63 \mu \mathrm{m}$ mesh size sieves and oven dried at $50{ }^{\circ} \mathrm{C}$ for $24 \mathrm{~h}$ for further analysis. For 17 samples, approximately $10 \mathrm{mg}$ of mixed benthic foraminifera was picked from the fraction 500-150 $\mu \mathrm{m}$ and sent to the Beta Analytics Limited Radiocarbon Laboratory in London or to the Poznan Radiocarbon Laboratory. Radiocarbon measurements were performed on cores GeoB 4802-1, 4803-1, 4805-1 and 4806-1. For core GeoB 4801-1, the age model of Scheurle et al. (2005) was used. All AMS ${ }^{14} \mathrm{C}$ ages were corrected for isotopic fractionation using $\delta^{13} \mathrm{C}$ values. Resulting conventional radiocarbon ages were converted into calendar years using the Calib 7.1 software (Stuiver et al. 2017) with the Marine 13 calibration curve (Reimer et al. 2013) considering the global mean reservoir age of 400 years (Bard 1998), which has been confirmed for nearby Danish marine waters (HeierNielsen et al. 1995). Results are given as the median probability calendar ages accompanied by the $1 \sigma(68.3 \%$ probability) and $2 \sigma$ ranges ( $95.4 \%$ probability).

Particle-size measurements of sediments of cores GeoB 4801-1 and 4806-1 were performed at the Senckenberg Institute, Department of Marine Science, Wilhelmshaven. Samples taken every $5 \mathrm{~cm}$ were desalted in semi-permeable hoses over $24 \mathrm{~h}$. The desalted samples were washed through a $63 \mu \mathrm{m}$ mesh size sieve to separate the mud fraction $(<63 \mu \mathrm{m})$ from the sand fraction ( $>63 \mu \mathrm{m})$. In addition, at the MARUM, University of Bremen, 17 samples of core GeoB 4803-1 were washed through a $63 \mu \mathrm{m}$ mesh size sieve to separate the mud fraction $(<63 \mu \mathrm{m})$ from the remaining sediment. The weight percent of the mud $(<63 \mu \mathrm{m})$ and the sand fractions $(>63 \mu \mathrm{m})$ were calculated by weighing the dry sediment before and after sieving.

\section{Results}

\section{XRF scanner data}

The relative $\mathrm{Zn}$ and $\mathrm{Pb}$ contents reveal similar background values in the lower parts of all cores, with $\mathrm{Zn}$ and $\mathrm{Pb}$ values ranging between $0.7 \%$ and $1.9 \%$ and between $0.3 \%$ and $1.1 \%$, respectively (Fig. 2). Towards the top of the cores, a significant increase of the relative $\mathrm{Zn}$ and $\mathrm{Pb}$ contents is observed reaching $\mathrm{Zn}$ and $\mathrm{Pb}$ values ranging between $1.2 \%$ and $2.9 \%$ and between $0.4 \%$ and $1.6 \%$, respectively (Fig. 2), except for GeoB 4804-1. The uppermost $8 \mathrm{~cm}$ of core GeoB 4804-1 was crushed and squeezed during retrieval, and, therefore, could not be analysed via XRF Core Scanner. These uppermost sediments enriched in $\mathrm{Zn}$ and $\mathrm{Pb}$ differed in both contents and thickness. Core GeoB 4803-1 shows both the thickest enriched sediment layer $(103 \mathrm{~cm})$ as well as very high relative $\mathrm{Zn}($ mostly $>2 \%)$ and $\mathrm{Pb}$ (mostly $>1 \%$ ) contents, with these high contents largely mirrored in core GeoB 4802-1, however, only in its upper $43 \mathrm{~cm}$. Both cores are characterised by a decreasing trend in the $\mathrm{Zn}$ and $\mathrm{Pb}$ relative contents in the uppermost sediments. In cores GeoB 4801-1, 4805-1 and 4806-1, the pattern of the $\mathrm{Zn}$ and $\mathrm{Pb}$ relative contents is very similar with the significant increase occurring at similar core depths of $15-25 \mathrm{~cm}$, with maximum relative $\mathrm{Zn}$ and $\mathrm{Pb}$ contents ranging between $1.9 \%$ and $2.3 \%$ and between $1.3 \%$ and $1.4 \%$, respectively.

\section{Quantitative XRF data}

The quantitative XRF measurements of the 66 samples used for the calibration of the semi-quantitative XRF core scanner data yielded $\mathrm{Zn}$ and $\mathrm{Pb}$ contents up to 300 and $100 \mathrm{ppm}$, respectively, whereas the background contents for $\mathrm{Zn}$ and $\mathrm{Pb}$ are $\sim 45$ and $\sim 20$ ppm, respectively (Fig. 3).

\section{Calibration of $\mathrm{Zn}$ and $\mathrm{Pb}$ scanner data}

Cross-plots between the quantitatively measured $\mathrm{Zn}$ and $\mathrm{Pb}$ contents and the corresponding relative contents based on the semi-quantitative scanner data show coefficients of determination $\left(R^{2}\right)$ of 0.65 for $\mathrm{Zn}$ and 0.72 for $\mathrm{Pb}$ (Fig. 3). For the $\mathrm{Zn}$ data, the cross-plot reveals one outlier (Fig. 3a) that, however, 


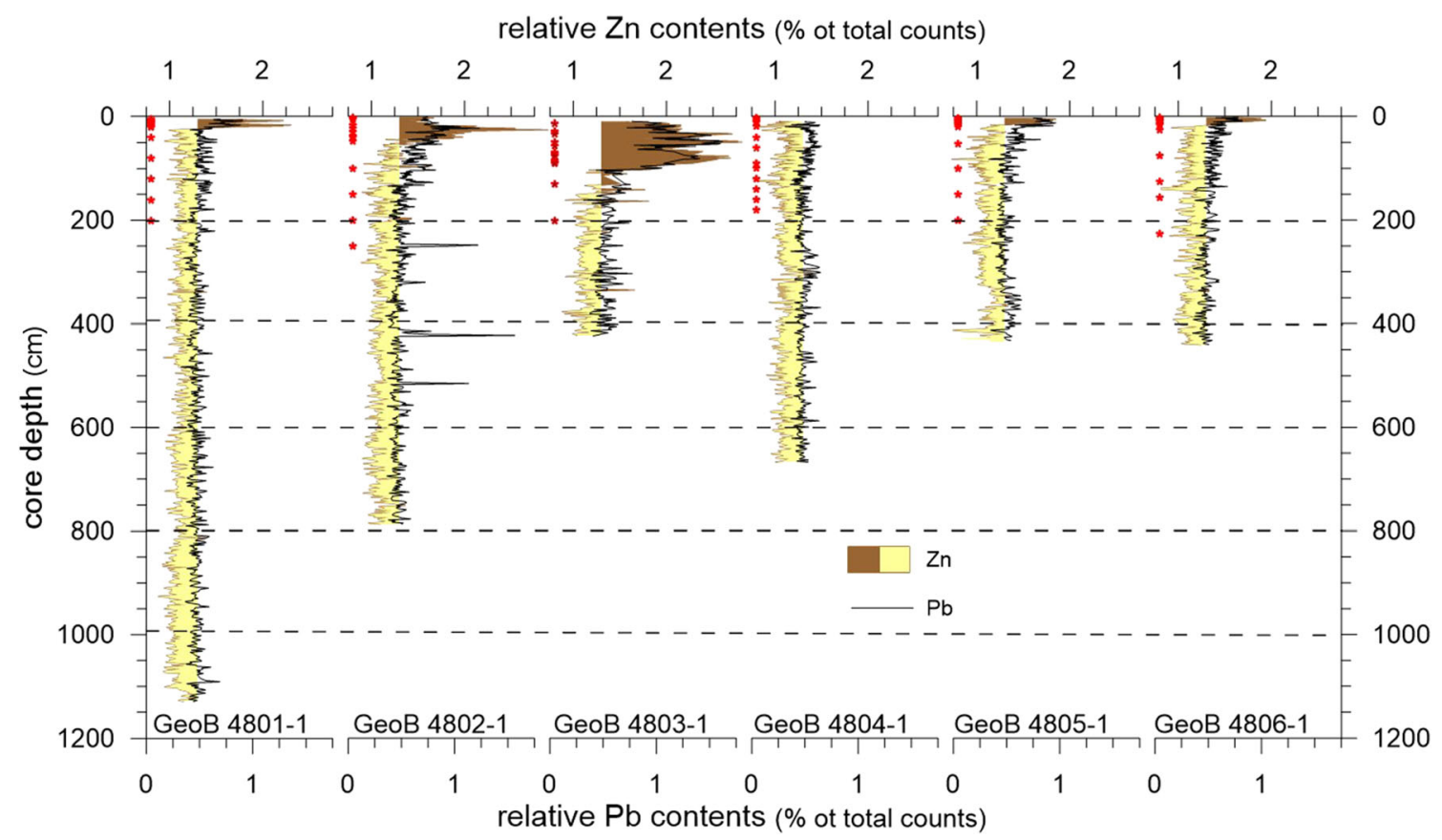

Fig. 2 XRF core scanner-based zinc ( $\mathrm{Zn}$; dark/light shading, cut-off at $1.3 \%)$ and lead $(\mathrm{Pb}$, black line) relative contents (percentage of the element counts in relation to the total counts) for six sediment cores

does not strongly influence the calibration. Thus, the equations used to calibrate the $\mathrm{Zn}$ and $\mathrm{Pb}$ XRF scanner data (see Fig. 3) include all 66 quantitatively measured samples.

\section{Calculated quantitative $\mathrm{Zn}$ and $\mathrm{Pb}$ contents}

For the lowermost core sections, the calibrated XRF Core Scanner data reveal mean absolute background contents of $\sim$ 41-46 ppm for $\mathrm{Zn}$ in the individual cores (Table 2, Fig. 4). After the increase in the upper core sections, the maximum zinc contents vary between 100 ppm (GeoB 4805-1) and 200 ppm (GeoB 4802-1 and GeoB 4803-1; Table 2, Fig. 4). The maximum contents of $\sim 200 \mathrm{ppm}$ in cores GeoB 4802-1 and GeoB 4803-1 correspond to almost five times the natural background. However, on average, the zinc contents of the from the Helgoland Mud Area. The red stars mark the position of 66 samples used for quantitative $\mathrm{Zn}$ and $\mathrm{Pb}$ measurements forming the base for the calibration of the semi-quantitative XRF core scanner results

upper polluted sediment layers are between 2.0 and 2.9 times higher than the natural background content (Table 2).

The $\mathrm{Pb}$ contents show a pattern very similar to the $\mathrm{Zn}$ contents, however, with lower values. The average $\mathrm{Pb}$ background contents in the lower parts of the cores range between 17 and 20 ppm (Fig. 4, Table 2), whereas average contents in the enriched layers are 29 to 55 ppm (Table 2). Thus, the $\mathrm{Pb}$ contents within the enriched layers are on average 1.5 to 2.7 times higher than the natural background contents (Table 2).

The $\mathrm{Zn} / \mathrm{Pb}$ ratios in the background sediments range between 2.1 (GeoB 4805-1) and 2.5 (GeoB 4801-1). In the upper sediment layers enriched in $\mathrm{Zn}$ and $\mathrm{Pb}$, this ratio changes in each core to higher values ranging from 2.3 (GeoB 4805-1) to 3.4 (GeoB 4801-1), thereby demonstrating a relatively larger increase in the $\mathrm{Zn}$ content compared to the $\mathrm{Pb}$ content.
Fig. 3 Cross-plots showing the correlation XRF core scannerbased relative contents ( $\%$ of total counts) and quantitatively measured absolute contents (ppm) of (a) zinc ( $\mathrm{Zn})$ and (b) lead $(\mathrm{Pb})$. The red dot in $(\mathbf{a})$ marks the outlier mentioned in the text
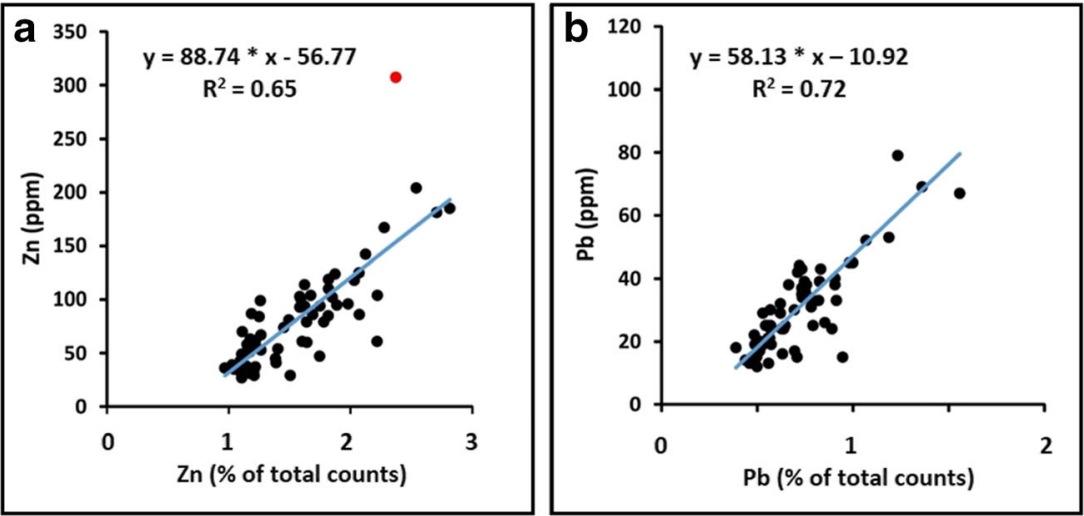
Table 2 Overview over the average $\mathrm{Zn}$ and $\mathrm{Pb}$ contents in the sediments of the Helgoland Mud Area (HMA)

\begin{tabular}{|c|c|c|c|c|c|c|c|c|}
\hline & Core number & $\begin{array}{l}\text { GeoB } \\
4801\end{array}$ & $\begin{array}{l}\text { GeoB } \\
4802\end{array}$ & $\begin{array}{l}\text { GeoB } \\
4803\end{array}$ & $\begin{array}{l}\text { GeoB } \\
4805\end{array}$ & $\begin{array}{l}\text { GeoB } \\
4806\end{array}$ & $\begin{array}{l}\text { GeoB } \\
\text { cores* }\end{array}$ & $\begin{array}{l}\text { All } \\
\text { cores** }\end{array}$ \\
\hline \multirow[t]{6}{*}{ Zinc (Zn) } & Maximum content (ppm) & 148 & 200 & 193 & 108 & 115 & $-1-$ & $-1-$ \\
\hline & $\begin{array}{l}\text { Average content enriched sediments } \\
\quad(\mathrm{ppm})\end{array}$ & 102 & 104 & 131 & 89 & 85 & 102 & $-1-$ \\
\hline & Background content (ppm) & 43 & 41 & 46 & 41 & 42 & 43 & $-1-$ \\
\hline & Excess content in enriched sediments & 59 & 64 & 86 & 48 & 43 & 60 & $-1-$ \\
\hline & Average enrichment factor & 2.3 & 2.6 & 2.9 & 2.2 & 2.0 & 2.4 & $-1-$ \\
\hline & Depth of increasing content $(\mathrm{cm})$ & 24 & 43 & 103 & 15 & 17 & 40 & 48 \\
\hline \multirow[t]{6}{*}{ Lead $(\mathrm{Pb})$} & Maximum content (ppm) & 42 & 61 & 83 & 45 & 37 & $-1-$ & $-1-$ \\
\hline & $\begin{array}{l}\text { Average content enriched sediments } \\
\text { (ppm) }\end{array}$ & 30 & 36 & 55 & 38 & 29 & 38 & $-1-$ \\
\hline & Background content (ppm) & 17 & 19 & 20 & 19 & 19 & 19 & $-1-$ \\
\hline & Excess content in enriched sediments & 13 & 17 & 35 & 19 & 10 & 19 & $-1-$ \\
\hline & Average enrichment factor & 1.8 & 1.9 & 2.7 & 2.0 & 1.5 & 2.0 & $-1-$ \\
\hline & Depth of increasing content $(\mathrm{cm})$ & 24 & 43 & 103 & 15 & 17 & 41 & 48 \\
\hline \multirow{3}{*}{$\begin{array}{l}\mathrm{Zn} / \mathrm{Pb} \\
\quad \text { ratio }\end{array}$} & Background sediments & 2.5 & 2.2 & 2.3 & 2.1 & 2.2 & 2.3 & $-1-$ \\
\hline & Enriched sediments & 3.4 & 2.9 & 2.4 & 2.3 & 3.0 & 2.8 & $-1-$ \\
\hline & Dry bulk density $\left(\mathrm{g} \mathrm{cm}^{-3}\right)$ & 0.86 & $-1-$ & $-1-$ & $-1-$ & $-1-$ & $-1-$ & $-1-$ \\
\hline
\end{tabular}

*Indicates the respective mean values for all GeoB cores; **considers also the data provided by Irion et al. (1987)). The numbers marked in bold are used to estimate the entire anthropogenic $\mathrm{Zn}$ and $\mathrm{Pb}$ inputs to HMA covering $500 \mathrm{~km}^{2}$. The value for the dry bulk density is based on the average dry bulk density of core GeoB 4801-1 (unpublished data)

\section{Particle size results}

The particle size distributions in cores GeoB 4801-1 and 4806-1 indicate similar patterns, with the sediment being dominated by mud $(<63 \mu \mathrm{m})$ with average contents of 87 wt.\% and 76 wt.\%, respectively (Fig. 5). In contrast, the sediments of core GeoB 4803-1 are generally coarser and show larger variations, with an average mud content of 50 wt.\% (Fig. 5).

\section{Radiocarbon ages}

The AMS- ${ }^{14} \mathrm{C}$ radiocarbon dates based on mixed benthic foraminifera reveal ages going back as far as $253 \mathrm{BC}$ (Table 3 ). In
Fig. 4 Calibrated absolute zinc (Zn; dark/light shading, cut-off at $60 \mathrm{ppm})$ and lead $(\mathrm{Pb}$, black line $)$ contents (ppm) of the sediment cores from the Helgoland Mud Area. Black stars mark the available ${ }^{14} \mathrm{C}$ datings with the respective ages given in $\mathrm{BC} / \mathrm{AD}$ notation. The thick grey line linked to core GeoB 4801-1 marks that part of the core for which the stratigraphy is based on correlation to historical (Scheurle et al. 2005) and instrumental (Scheurle et al. 2003) data

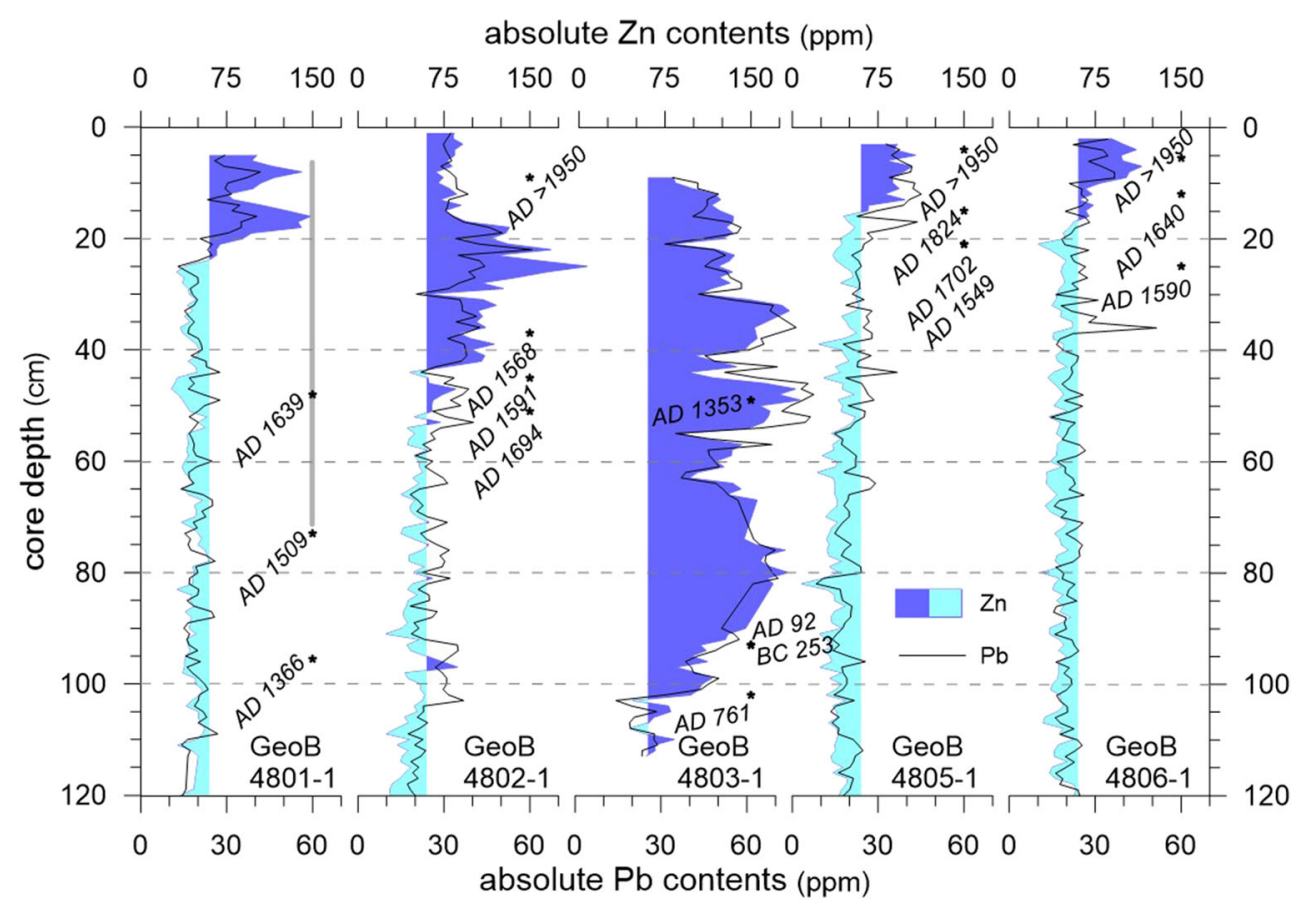




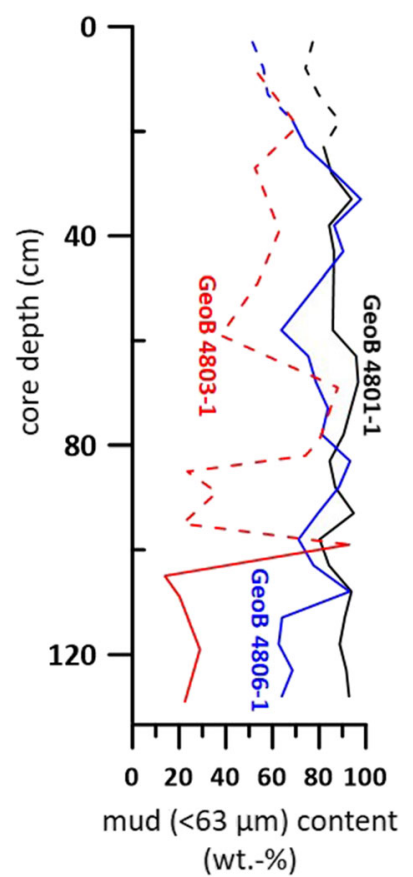

Fig. 5 Weight contents of mud $(<63 \mu \mathrm{m})$ for sediment cores GeoB 48011, 4806-1 and GeoB 4803-1 from the Helgoland Mud Area. For all three cores, data for the background sediments are marked by continuous lines, whereas data for the sediments enriched in $\mathrm{Zn}$ and $\mathrm{Pb}$ are given in dashed lines according to the indicated colour code

some of the cores, age reversals, indicating possible effects of some re-sedimentation and/or bioturbation, can be observed (Fig. 6). Nevertheless, when orienting along the youngest dates (see discussion) or along overlapping sigma ranges for all four investigated cores, average sedimentation rates result in rather consistent values (Fig. 6). For the past centuries, these range between 0.5 and $1.2 \mathrm{~mm}$ year $^{-1}$, close to the value of $1.4 \mathrm{~mm}_{\text {year }}{ }^{-1}$ since AD 1600 for core GeoB 4801-1 taken from a detailed age model (Scheurle et al. 2005). Highest rates of $>1 \mathrm{~mm}$ year $^{-1}$ are being restricted to the central and northwestern HMA.

\section{Discussion}

\section{The spatial pattern of enhanced $\mathrm{Zn}$ and $\mathrm{Pb}$ contents in the Helgoland Mud Area}

In a first spatial assessment, Irion et al. (1987) reported enhanced $\mathrm{Zn}$ contents, measured from the fraction $<2 \mu \mathrm{m}$, in the uppermost sediments of 21 sediment cores distributed all over the HMA (Fig. 7) and even beyond its limits as defined by von Haugwitz et al. (1988). The trend towards thicker Zn-enriched deposits in the eastern HMA reported by Irion et al. (1987) is also reflected in the new data presented here, based on the $\mathrm{Zn}$ content in the total sediment (Fig. 7). Of course, the use of sediments comprising different grain sizes in both studies can be problematical when comparing such different data sets directly, especially in terms of quantification (see, e.g., Birch 2017). Consequently, both data sets are not compared quantitatively here. In contrast, the spatially more extensive data (Irion et al. 1987) are only compared to the new data in a qualitative way to demonstrate the coherent spatial pattern of

Table 3 Overview of the AMS- ${ }^{14} \mathrm{C}$ dates in the sediments based on the analysis of mixed benthic foraminifera

\begin{tabular}{|c|c|c|c|c|c|c|}
\hline $\begin{array}{l}\text { Core } \\
\text { number } \\
\text { GeoB }\end{array}$ & $\begin{array}{l}\text { Depth } \\
(\mathrm{cm})\end{array}$ & $\begin{array}{l}\text { Laboratory } \\
\text { identification }\end{array}$ & $\begin{array}{l}\text { Conventional radiocarbon } \\
\text { age (BP) }\end{array}$ & $1 \sigma$ range of calendar age & $\begin{array}{l}2 \sigma \text { range of calendar } \\
\text { age }\end{array}$ & $\begin{array}{l}\text { Median } \\
\text { probability } \\
\text { calendar age }\end{array}$ \\
\hline $4802-1$ & 9 & Poz-65886 & Modern & Modern & Modern & Post 1950 \\
\hline $4802-1$ & 37 & Beta-361007 & $690 \pm 30$ & AD 1518 to 1626 & AD 1480 to 1660 & AD 1568 \\
\hline $4802-1$ & 45 & Beta-361008 & $660 \pm 30$ & $\mathrm{AD} 1544$ to 1636 & AD 1498 to 1676 & AD 1591 \\
\hline $4802-1$ & 51 & Poz-65913 & $560 \pm 30$ & AD 1645 to 1728 & AD 1568 to 1827 & AD 1694 \\
\hline $4803-1$ & 49 & Beta-361009 & $970 \pm 30$ & AD 1314 to 1393 & AD 1286 to 1427 & AD 1353 \\
\hline $4803-1$ & 93 & Poz-66014 & $2200 \pm 50$ & $\mathrm{AD} 14$ to 165 & $\mathrm{BC} 55$ to $\mathrm{AD} 252$ & AD 92 \\
\hline 4803-1 & 93 & Poz-75174 & $2475 \pm 30$ & BC 324 to $\mathrm{BC} 195$ & $\mathrm{BC} 365$ to $\mathrm{BC} 127$ & BC 253 \\
\hline $4803-1$ & 102 & Beta-361010 & $1570 \pm 30$ & $\mathrm{AD} 702$ to 805 & AD 676 to 879 & AD 761 \\
\hline $4805-1$ & 4 & Poz-65914 & $55 \pm 30$ & Modern & Modern & Post 1950 \\
\hline $4805-1$ & 15 & Beta-361011 & $450 \pm 30$ & $\begin{array}{l}\text { AD } 1724 \text { to } 1744 ; 1751 \\
\quad \text { to } 1790 ; 1800 \text { to } 1892 ; 1944 \text { to } \\
1950\end{array}$ & AD 1712 to 1950 & AD 1824 \\
\hline $4805-1$ & 21 & Poz-65916 & $555 \pm 35$ & $\mathrm{AD} 1650$ to 1762 & AD 1566 to 1847 & AD 1702 \\
\hline $4805-1$ & 21 & Poz-75173 & $710 \pm 30$ & AD 1491 to 1594 & AD 1467 to 1649 & AD 1549 \\
\hline $4806-1$ & 5.5 & Poz-75172 & $315 \pm 30$ & Modern & Modern & Post 1950 \\
\hline $4806-1$ & 12 & Beta-361012 & $650 \pm 40$ & $\mathrm{AD} 1540$ to 1670 & $\mathrm{AD} 1500$ to 1690 & AD 1640 \\
\hline $4806-1$ & 25 & Poz-65918 & $660 \pm 40$ & AD 1539 to 1649 & AD 1489 to 1683 & AD 1590 \\
\hline
\end{tabular}




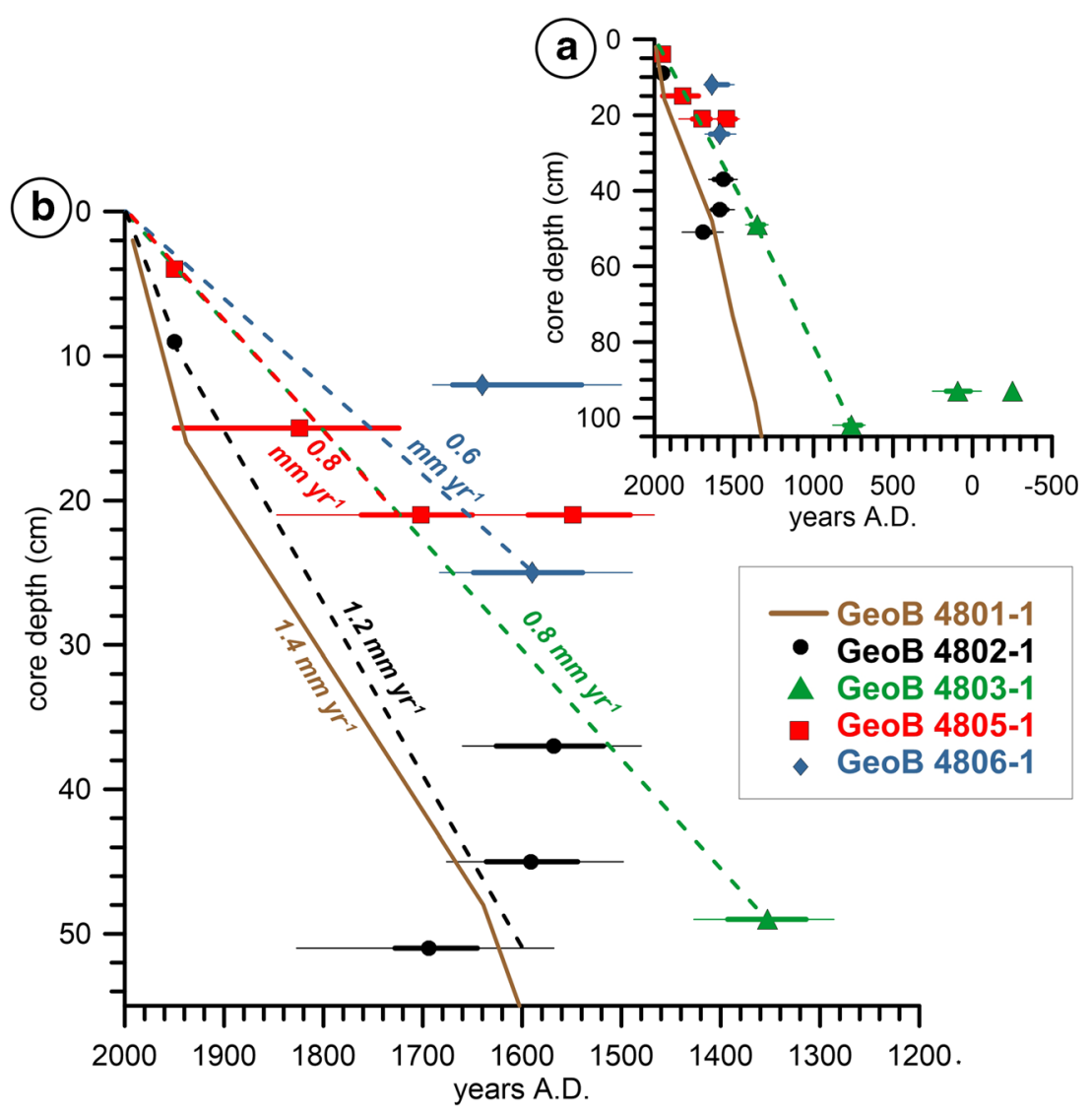

Fig. 6 Age vs. depth plots for five sediment cores from the Helgoland Mud Area showing an overview of calibrated AMS radiocarbon ages (a) and an enlarged view of results from the upper $54 \mathrm{~cm}$ of the cores. 1sigma (bold error bars) and 2-sigma (thin error bars) ranges are added to the individual data points. Average estimated sedimentation rates are indicated for each core. These are based on assuming a core top age of 1997 AD (year of sampling) in combination with the dashed fit lines, which are either oriented on distinct ages or on fitting overlapping sigma ranges of adjacent datings, thereby excluding obvious outliers resulting

heavy metal contamination in the HMA. This spatial pattern of gradually increasing thicknesses of the Zn-enriched layers from NW to SE is a clear indicator for continuous, essentially undisturbed sedimentation in the HMA as already pointed out by Irion et al. (1987). The pattern provided by the Zn contents in the GeoB cores studied here is almost completely mirrored in the $\mathrm{Pb}$ contents (Fig. 4).

\section{Sedimentation rates in the Helgoland Mud Area}

It has to be admitted here that the radiocarbon data are partly ambiguous as they are marked by several age reversals, which, however, can be expected in such a dynamic, relatively shallow water setting. When in a sediment core older sediments/ fossils/dates occur on top of younger ones, it is obvious that these are reworked. Otherwise, it cannot be explained how the younger material got deeper into the core. Of course, arguing for reworking at one point also allows questioning the from reworking. Aligning data of core GeoB 4801-1 to the instrumental data of the Helgoland roads time series confirms that for this core the topmost data point $(2 \mathrm{~cm})$ represents the early 1990s (Scheurle and Hebbeln 2003). To treat all cores in a consistent manner, the year of sampling has been used as top age for all of them. Data for core GeoB 4801-1 are taken from Scheurle et al. (2005), with the sedimentation rate estimate provided here being based on an age of $1600 \mathrm{AD}$ at $515 \mathrm{~cm}$ core depth

'younger ages', which also might be reworked. However, to put it to the other extreme, if reworking of everything is assumed, it would be difficult to explain (1) the consistent regional pattern of zinc enrichment in the HMA developing along smooth gradients and (2) the consistent pattern of sedimentation rates resulting from orienting on the youngest ages. Finally, the reliability of the ${ }^{14} \mathrm{C}$ dates obtained from core GeoB 4801-1, supported by the comparison to historical and instrumental data (Scheurle and Hebbeln 2003; Scheurle et al. 2005), gives some credibility to the approach followed here, considering the resulting ${ }^{14} \mathrm{C}$ ages as reliable in the first place, unless reworking becomes obvious by age reversals. Of course, we cannot exclude that the dated material revealing 'youngest' ages has been reworked, but this is a problem inherent to all non-laminated sediments.

At first glance, the observation of a coherent sediment layer enriched in heavy metals that covers almost the entire HMA may point to an isochronous onset of enhanced heavy metal 
Fig. 7 Zinc (Zn) distribution map (modified after Irion et al. 1987) showing the total $\mathrm{Zn}$ contents $(\mathrm{ppm})$ in the upper $\mathrm{Zn}$-enriched sediments of the six sediment cores from the Helgoland Mud Area (HMA) investigated here (marked in red) and the $\mathrm{Zn}$ content above the natural background in the particle size fraction $<2 \mu \mathrm{m}$ of the sediment cores studied by Irion et al. (1987) (marked in black). In core GeoB 4804-1 from the north-eastern HMA, where the enriched layers are thinnest, no enriched layer could be found due to lacking data from the uppermost $8 \mathrm{~cm}$ of that core that probably contained the contaminant signal

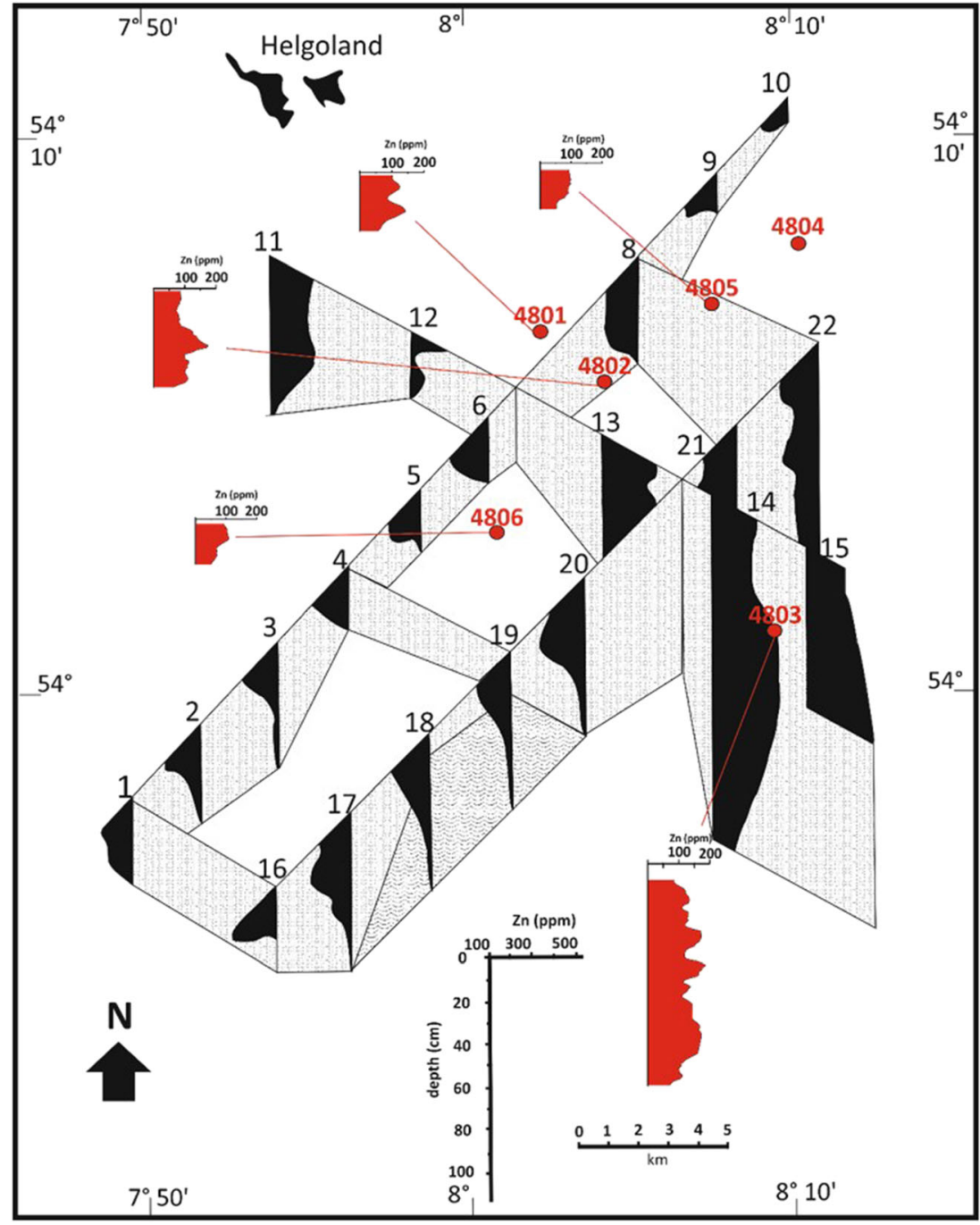

deposition as also proposed by Irion et al. (1987). Obviously, such an interpretation would require a significant increase in sedimentation rates from west $(\sim 20$-cm-thick enriched layer) to east (> 100-cm-thick enriched layer; Fig. 7). However, this is in contrast to the newly obtained radiocarbon dates (Table 3), which reveal rather similar sedimentation rates at
Fig. 8 Precise dating of the onset of enhanced zinc deposition at site GeoB 4801-1 in the Helgoland Mud Area with the stratigraphy and the resulting sedimentation rates for this core being based on correlation to instrumental (Scheurle et al. 2003) and historical (Scheurle et al. 2005) records

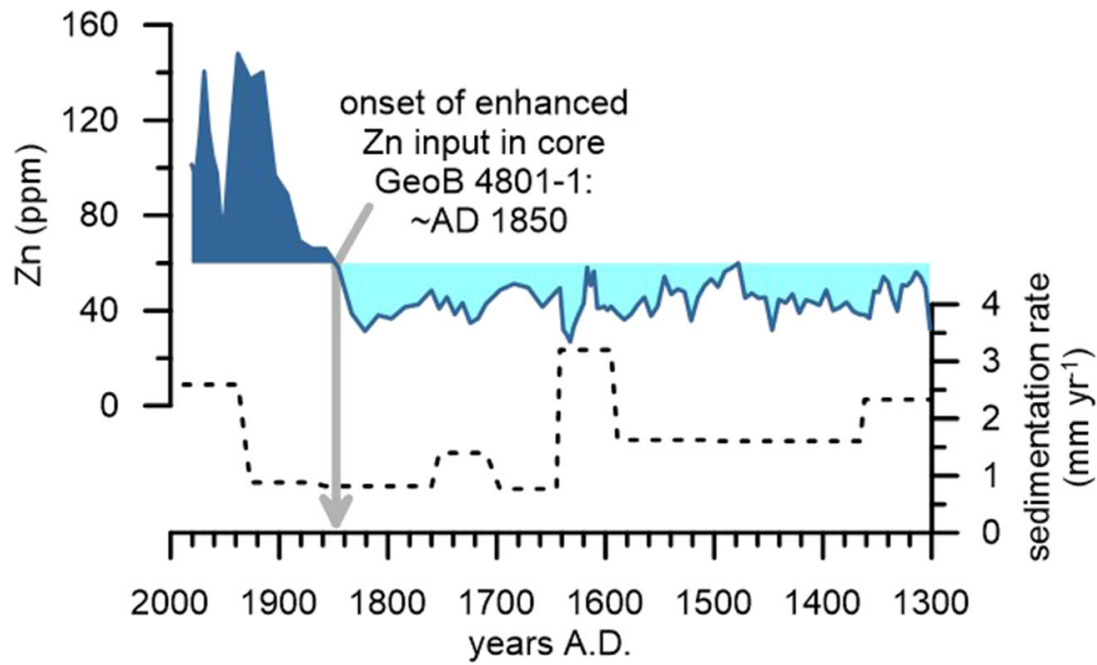


all sites, actually with a slight increase to the northwest, i.e. opposite to the expected direction (Fig. 6). In the uppermost $50 \mathrm{~cm}$ of the sediment column, all cores show decreasing ages towards the top with a rather narrow range of average sedimentation rates of 0.5 to $1.2 \mathrm{~mm}$ year $^{-1}$ close to the sedimentation rate of $1.4 \mathrm{~mm}$ year ${ }^{-1}$ obtained for the well-dated core GeoB 4801-1 (Scheurle et al. 2005; Fig. 6). Further downcore, sedimentation rates in cores GeoB 4801-1 and 4803-1 remain rather stable (Fig. 6a) and follow roughly the same trend as above. Actually, the spatial pattern revealed by the sedimentation rates mirrors the thickness of the HMA (cf. Fig. 1; Von Haugwitz et al. 1988 with highest sedimentation rates of $>$ $1 \mathrm{~mm}$ year $^{-1}$ in cores GeoB 4801-1 and 4802-1 fitting HMA thicknesses of $>\sim 18 \mathrm{~m}$ and vice versa for cores GeoB 4803-1, 4805-1 and 4806-1.

The observed difference in sedimentation rate between the south-eastern core GeoB 4803-1 (0.8 $\left.\mathrm{mm} \mathrm{year}^{-1}\right)$ and the two north-western HMA cores GeoB 4801-1 and 4802-1 ( $1.3 \mathrm{~mm} \mathrm{year}^{-1}$ ) is also reflected in the grain-size distribution with lower amounts of mud in the slower accumulating setting. This would be in line with the assumption that at the slightly shallower site GeoB 4803-1 a higher hydrodynamic energy reduces the deposition of finer material and, thus, the overall sedimentation.

Considering temporal variability in sedimentation rates not resolved by the new data presented here, but which are obvious for site GeoB 4801-1 at which the most recent sediments got deposited at a rate of $2.6 \mathrm{~mm}_{\text {year }}{ }^{-1}$ (Scheurle et al. 2005; Fig. 8), these sedimentation rates are in agreement with radiocarbon-based sedimentation rate estimates of $3 \mathrm{~mm}$ year $^{-1}$ for the central HMA obtained by Serna et al. (2010). Deviating from these results are sedimentation rates of $7.7 \mathrm{~mm}_{\text {year }}{ }^{-1}$ reported by Dominik et al. (1978). However, this sediment core from an unreported position somewhere south of Helgoland is marked by event-driven sedimentation (storm flood deposits) and erosion (Dominik et al. 1978) and, thus, it is probably not well comparable to the HMA records described here.

For core GeoB 4801-1 the onset of enhanced heavy metal deposition can be rather precisely dated to $\sim \mathrm{AD}$ 1850 (Fig. 8). Based on new XRF scanning results presented here that move the increase in $\mathrm{Zn}$ counts approximately $12 \mathrm{~cm}$ further up in the core, the previously published earlier age for this onset $(\sim \mathrm{AD} 1750$ in Hebbeln et al. 2003) has been identified as an artefact. Assuming an isochronous onset over the entire HMA at $\sim$ AD 1850 would stretch the range of sedimentation rates from $1.4 \mathrm{~mm}$ year $^{-1}$ (e.g. core GeoB 4801-1) to > $20 \mathrm{~mm}$ year $^{-1}$ (for a sediment core with $>300 \mathrm{~cm}$ of polluted sediments; Irion et al. 1987), which would account for a 15 -fold increase in sedimentation rate from $\mathrm{NW}$ to SE over only $\sim 10 \mathrm{~km}$. As such high rates in the order of centimetres per year have been tentatively linked to dredging activities in the Elbe estuary during the past few decades, sedimentation rates must have increased tremendously compared to the natural setting, when only little amounts of river borne sediments are expected to have reached the German Bight (Irion et al. 1987). Furthermore, a dramatic increase in sedimentation rates triggered by dredging would not align with an onset of enhanced sedimentation already as early as AD 1850 . The high-resolution stratigraphy of core GeoB 4801-1 reveals (1) no major increase in sedimentation rate paralleling the onset of enhanced heavy metal input and (2) only slightly varying sedimentations rates since $\mathrm{AD} 1300$ not exceeding $3.2 \mathrm{~mm}$ year $^{-1}$ (Fig. 8). Following the idea of Irion et al. (1987) that in the mid-twentieth century enhanced dredging activities in the estuaries might have caused enhanced sedimentation in the HMA, the minor increase in sedimentation rate in core GeoB 4801-1 around AD 1940 might relate to this; however, this occurred almost a century after the input of $\mathrm{Zn}$ and $\mathrm{Pb}$ increased (Fig. 8).

Based on these considerations, we conclude that the sedimentation rate pattern based on the available radiocarbon dates (Fig. 6) provides the best representation of the history of sediment deposition in the HMA. Consequently, in the following we argue for a diachronous onset of enhanced heavy metal input.

\section{The temporal pattern of increasing $\mathrm{Zn}$ and $\mathrm{Pb}$ inputs to the Helgoland Mud Area}

Based on the radiocarbon dates, this diachronous onset can be followed along the various core sites. The first enrichments of $\mathrm{Zn}$ and $\mathrm{Pb}$ occurred in core GeoB 4803-1 in the southeast as early as $\sim \mathrm{AD} 760$ (Fig. 4). A very early age for this onset is supported by two accompanying ${ }^{14} \mathrm{C}$-ages in this core, also providing rather old, though reworked ages (Fig. 6a). The close-by core no. 14 (Fig. 7, Irion et al. 1987) provided a pollen-based 'pre-medieval' (i.e. AD 500) age estimate for a sediment sample taken in $2 \mathrm{~m}$ core depth from directly below the polluted sediments (Irion et al. 1987; von Haugwitz et al. 1988). This rough age estimate would result in a sedimentation rate slightly above $1 \mathrm{~mm} /$ year, thus in a similar order to the sedimentation rate estimates provided here. From the south-easternmost part of the HMA, the enhanced input of $\mathrm{Zn}$ and $\mathrm{Pb}$ progressed north-westward to reach site $\mathrm{GeoB}$ 4806-1 in the southernmost and site GeoB 4802-1 in the central HMA by $\sim \mathrm{AD} 1650-1750$. Advancing further to the northwest, sites GeoB 4805-1 and GeoB 4801-1 were reached at AD 1750-1850, respectively. Thus, the enhanced input of heavy metals to the HMA follows a time-transgressive pattern advancing from site GeoB 4803-1 towards the other sites with an average velocity of $\sim 10 \mathrm{~m}$ year $^{-1}$ (range for the four core sites, $9.5-10.6 \mathrm{~m} \mathrm{year}^{-1}$ ). 


\section{Sources of the enhanced $\mathrm{Zn}$ and $\mathrm{Pb}$ input}

The constant low background values in the $\mathrm{Zn}$ and $\mathrm{Pb}$ contents as well as their significant increase in historical times (Figs. 2 and 4) indicate that the enhanced heavy metal inputs are due to anthropogenic activities. This is further corroborated by the $\mathrm{Zn} / \mathrm{Pb}$ ratios, which show a distinct increase from 2.25 in the background sediments to 2.72 in the polluted sediments. This shift indicates a change in the source area, with the source(s) for the enhanced $\mathrm{Zn}$ and $\mathrm{Pb}$ inputs most likely differing from those contributing to the older sediments.

Earlier studies attributed enhanced $\mathrm{Zn}$ and $\mathrm{Pb}$ contamination to a variety of anthropogenic sources, including fossil fuel burning and sewage effluent since the 1850s (Dominik et al. 1978), dumping of acidic iron waste from titanium dioxide production (Dominik et al. 1978) and dredging activities in the neighbouring estuaries (Irion et al. 1987) both since the 1950s. From these possible sources, only the dredging activities could have resulted in the necessary increase in sedimentation required to form a $>$ 300-m-thick polluted sediment package within decades. Seeing the well-documented onset of $\mathrm{Zn}$ and $\mathrm{Pb}$ pollution at $\mathrm{AD} 1850$ in core GeoB 4801-1, this would require - at least in the southeastern HMA where the polluted layer is thickest - two different sedimentation processes to explain first slow aggrading polluted sediments from $\sim \mathrm{AD} 1850$ to $\sim \mathrm{AD} 1950$, and much higher sedimentation afterwards. However, the comparably coarser sediments found at site GeoB 4803-1 (Fig. 5) characterise the older unpolluted as well as the younger polluted sediments and do not provide any hint to a dramatic change in the sedimentation process. Actually, as pointed out above, the continuous high sand content supports the interpretation of having comparably low sedimentation rates at this 'shallower' site, where higher energies hamper the sedimentation of finer material. Thus, the sources proposed by Dominik et al. (1978) and Irion et al. (1987) are inconsistent with the new data provided here, which clearly demonstrate a much earlier onset of heavy metal enrichment (Fig. 4).

However, the new data do support the interpretation by Hebbeln et al. (2003), which related the anthropogenic signal to early mining activities in the Harz Mountains and in the Erzgebirge, both of which are well-known, long-established mining areas along the tributaries of the Elbe and Weser Rivers. Although the new data indicate a much earlier onset $(\sim$ AD 760$)$ than estimated before (Hebbeln et al. 2003), evidence for mining activities, especially in the Harz Mountains, extends back to $\sim 3500$ years BP (Monna et al. 2000). Furthermore, findings of enhanced $\mathrm{Zn}$ and $\mathrm{Pb}$ contents in sediments from the western foothills of the Harz Mountains with an estimated Karolingian age (AD 825 to AD 890) (Matschullat et al. 1997) and in Weser river sediments since AD 800 (Ortlam 1989) clearly document a fluvial transport of heavy metals from the mining locations towards the German Bight. In particular, a fluvial link to the Harz Mountains is indicated by increasing heavy metal contents in Weser sediments downstream of the confluence with the Aller River, a Weser tributary draining parts of the Harz Mountains (Pache et al. 2008). Earlier mining activities in the Harz Mountains, dating back to 3500 years BP (Monna et al. 2000), may have been conducted at a smaller scale than more recent mining, without contributing a detectable level of $\mathrm{Zn}$ and $\mathrm{Pb}$ to the HMA. Thus, the timing of the onset of enhanced $\mathrm{Zn}$ and $\mathrm{Pb}$ deposition in the HMA at $\sim \mathrm{AD} 760$ probably is a function of mining intensity/methodology and on the velocity of the signal propagation from the source areas through the rivers to the southern North Sea. Remarkable is the rather fast increase of $\mathrm{Zn}$ and $\mathrm{Pb}$ input at site GeoB 4803-1 at a very early time soon after its initiation at $\sim \mathrm{AD} 760$ (Fig. 4). As independent of the timing one usually would expect a gradual increase in pollution, the sudden increase observed here most likely is the result of changes in the sedimentological setting, possibly related to the positioning and strength of the mesoscale eddy controlling the sedimentation in the HMA (Mayer 1995).

Interestingly, on the nearby island of Helgoland, copper $(\mathrm{Cu})$ was mined and smelted, probably from the early Bronze Age to medieval times (Schulz 1981). However, average $\mathrm{Zn} / \mathrm{Pb}$ ratios of 0.27 in copper slices found near Helgoland (Schulz 1981) are significantly different from those found in our cores (2.25 to 2.72), which show no sign of enhanced $\mathrm{Cu}$ deposition. As heavy metal-enriched Weser sediments reveal $\mathrm{Zn} / \mathrm{Pb}$ ratios of $>2$ (Ortlam 1989; Monna et al. 2000) and rather low $\mathrm{Cu}$ enrichments (Pache et al. 2008), heavy metals in the HMA sediments are most likely not related to copper mining on Helgoland, but are derived from the mainland rivers.

Actually, deposition of large-scale lead pollution has occurred for at least 3000 years in Europe with metal production and smelting as the main sources until the twentieth century (Renberg et al. 2001). The first major anthropogenic increase occurred during Roman times, when $\mathrm{Pb}$ contents in a Spanish peat bog revealed a fivefold increase above natural background values (Martinez Cortizas et al. 1997). In Swedish lakes, isotopic traces of local mining occur as early as $\mathrm{AD}$ 960 (Bindler et al. 2009) followed by significant increases in $\mathrm{Pb}$ contents in Baltic Sea sediments at AD 1200 (Zillen et al. 2012) and in lake sediments by AD 1500 (Bindler et al. 2009). Therefore, early shedding of heavy metal pollution around $\mathrm{AD}$ 800 originating from the Harz Mountains as recorded in Harz creek sediments (Matschullat et al. 1997), in Weser river sediments (Ortlam 1989) and in the HMA (this study) fits well into a pan-European picture.

\section{The time-transgressive pattern of enhanced $\mathrm{Zn}$ and $\mathrm{Pb}$ input}

The time-transgressive SE to NW advance of enhanced $\mathrm{Zn}$ and $\mathrm{Pb}$ inputs with on average $10 \mathrm{~m}^{\text {year }}{ }^{-1}$ across the HMA might be due to an increasing contribution of river-borne 
material to the sedimentation in the HMA. For the period $\sim \mathrm{AD}$ 1250 to $\sim$ AD 1650 , overlapping with the NW-ward advance of the higher heavy metal input, decreasing salinities over the HMA have been explained with increasing river discharge to the German Bight (Scheurle et al. 2005). As only little riverborne material is expected to leave the estuaries (Irion et al. 1987), a further seaward advection of riverine waters stimulated by a higher discharge might have been able to change the composition of the HMA sediments qualitatively (higher heavy metal content) without affecting them quantitatively (as reflected in core GeoB 4801 sedimentation rate record; Fig. 8). Such a relative increase of the heavy metal load with increasing transport routes also have been described for the recent German Bight setting (Hinrichs et al. 2002). In line with the decreasing salinities corresponding to an enhanced presence of riverine waters, this impact on the composition of the HMA sediments probably has advanced progressively NWward. However, other scenarios invoking changes in the palaeogeography and/or sea level also might be generally feasible, but appear less likely on the time scales considered here.

In this context, one might wonder why the 1970s peak in atmospheric lead pollution resulting from gasoline burning has no strong expression in the HMA sediments, although its fast spreading makes it already detectable in the ocean waters of the entire North Atlantic Ocean and even in corals from Bermuda (Boyle et al. 2014). The lack of such a signal in the HMA most likely is caused by the relatively minor contribution of atmospheric $\mathrm{Pb}$ to the deposition there. Ottley and Harrison (1991) provided an estimate for the atmospheric $\mathrm{Pb}$ deposition in the German Bight of $\sim 600 \mu \mathrm{g} \mathrm{m}^{-2}$ month $^{-1}$ based on data from 1980, which would amount to an annual deposition of $7.2 \mathrm{mg} \mathrm{m}^{-2}$ year $^{-1}$. Taking $30 \mathrm{ppm}$ as the average $\mathrm{Pb}$ content in the polluted HMA sediments in core GeoB 4801-1 (Table 2) and its average sedimentation rate of $1.4 \mathrm{~mm}$ year $^{-1}$ (considering a dry bulk density of $0.9 \mathrm{~g} \mathrm{~cm}^{-3}$; Hebbeln, unpublished data), the sedimentary $\mathrm{Pb}$ deposition is $38 \mathrm{mg} \mathrm{m}^{-2}$ year ${ }^{-1}$ (using the ${ }^{210} \mathrm{~Pb}$-dating derived sedimentation rate of $2.6 \mathrm{~mm} \mathrm{year}^{-1}$ for the uppermost sediments, this number would increase to $70 \mathrm{mg} \mathrm{m}^{-2}$ year $^{-1}$ ). Thus, in coastal depocentres such as the HMA the atmospheric $\mathrm{Pb}$ input plays a subordinate role, which is in agreement with results from the Gulf of Gdansk in the Baltic Sea for example, where the riverine contribution also clearly dominates the atmospheric input (Zaborska 2014).

As the heavy metal contents in such depocentres strongly depend on the local setting, absolute values for (sub-)recent polluted sediments can be quite variable, ranging for $\mathrm{Pb}$ from low values of 30-50 ppm in the HMA and off the Polish coast (Zaborska et al. 2017) to values of $>100 \mathrm{ppm}$ in Baltic Sea sediments (Bindler et al. 2009; Zillen et al. 2012). Put into a sedimentation/accumulation rate context, even strong local variability becomes obvious as, e.g., for a set of six rather young (post-AD 1850) sediment cores collected from the
Gulf of Gdansk, Baltic Sea. These show rather consistent average $\mathrm{Pb}$ contents ranging from 35 to $67 \mathrm{ppm}$, which, however, show a large spread of $9-106 \mathrm{mg} \mathrm{m}^{-2}$ year $^{-1}$ in the average $\mathrm{Pb}$ accumulation rates (Zaborska 2014), with both ranges covering the values found in the HMA.

\section{Total anthropogenic $\mathrm{Zn}$ and $\mathrm{Pb}$ input to the mud area}

Using average values for the thickness of the uppermost sediment layer characterised by elevated $\mathrm{Zn}$ and $\mathrm{Pb}$ contents, this layer's average $\mathrm{Zn}$ and $\mathrm{Pb}$ contents above the natural background and the sediment's dry bulk density of $\sim 0.86 \mathrm{~g} \mathrm{~cm}^{-3}$ (see Table 2), the total anthropogenic $\mathrm{Zn}$ and $\mathrm{Pb}$ input to the whole HMA was estimated. Applying these values to an overall extent of the HMA of $500 \mathrm{~km}^{2}$, a total volume of $245,000,000 \mathrm{~m}^{3}$ or $0.245 \mathrm{~km}^{3}$ of enriched sediments can be assumed. This volume in combination with the average $\mathrm{Zn}$ and $\mathrm{Pb}$ contents above the natural background of $59 \mathrm{ppm}$ for $\mathrm{Zn}$ and of $19 \mathrm{ppm}$ for $\mathrm{Pb}$ and the average bulk density of $0.86 \mathrm{~cm}^{3}$ add up to rough estimate of anthropogenic induced inputs of $\sim 12,000 \mathrm{t}$ of $\mathrm{Zn}$ and $\sim 4000 \mathrm{t}$ of $\mathrm{Pb}$ to the HMA. Although the density obtained from only one core might vary within the HMA, such variability would not affect the order of magnitude of the estimated anthropogenic $\mathrm{Zn}$ and $\mathrm{Pb}$ inputs.

At first glance, these numbers seem to be rather large. However, the loads of the suspended heavy metals in the Elbe showed peak values of $4400 \mathrm{t}$ of $\mathrm{Zn}$ and $350 \mathrm{t}$ of $\mathrm{Pb}$ per year at the station Magdeburg in 1986 (FGG Elbe 2010) putting the numbers from the HMA into a broader perspective. Furthermore, in only 1 year, in 2014 , a total of $4.5 \mathrm{Mm}^{3}$ of sediments containing $\sim 180 \mathrm{t}$ of $\mathrm{Pb}$ and $\sim 1600 \mathrm{t}$ of $\mathrm{Zn}$ was dredged from the port of Hamburg. At the Tonne E3 dumping site located $\sim 15 \mathrm{~km}$ south of Helgoland, and close to the HMA, $~ 440,000 \mathrm{t}$ of this dredged material was dumped containing $\sim 15 \mathrm{t}$ of $\mathrm{Pb}$ and $\sim 104 \mathrm{t}$ of $\mathrm{Zn}$ (Hamburg Port Authority 2015). Thus, the heavy metals deposited in the HMA obviously only reflect a fraction of the heavy metals that are present in the marine system of the German Bight. Most likely, other depocentres like the estuaries of the Elbe and Weser rivers, and the Skagerrak, which is the most prominent fine sediment depocentre in the North Sea, also serve as sinks for anthropogenic heavy metal inputs to the German Bight (Hinrichs et al. 2002).

Interestingly, the high amounts of $\mathrm{Zn}$ and $\mathrm{Pb}$ in the dredged material dumped close to the HMA in recent years/decades seem to not have caused any increase in contamination within the cores analysed here. Instead, most of our cores show a decline in the $\mathrm{Pb}$ and $\mathrm{Zn}$ contents in the youngest sediments. Therefore, it seems that these dumped sediments somehow do not enter the eddy-controlled depositional system of the HMA, maybe due to the particle dynamics linked to the dumping process that might release only a fraction of the dumped material into a sustained suspension. Alternatively, the 
declining $\mathrm{Zn}$ and $\mathrm{Pb}$ contents in the youngest HMA sediments may reflect reduced river sourced SPM loads due to the construction of various dams along the Weser and Elbe rivers.

\section{Conclusion}

In contrast to earlier interpretations linking enhanced heavy metal deposition in the HMA to increasing inputs of estuarine sediments remobilised by dredging activities throughout the last few decades, new data reveal that $\mathrm{Zn}$ and $\mathrm{Pb}$ enrichment in the HMA sediments follows a regional, time-transgressive pattern beginning already as early as AD 760. At this time, enhanced $\mathrm{Zn}$ and $\mathrm{Pb}$ inputs first reached the south-eastern HMA, probably as a consequence of increased mining activities in the Harz Mountains and the Erzgebirge within the catchments of the Weser and Elbe rivers that drain into the German Bight close to the HMA. Increasing river discharges since at least $\mathrm{AD} 1250$ probably have triggered the gradual advance of the heavy metal across the HMA from SE to NW reaching its north-western part by AD 1850 . However, as river-borne sediments are expected to only contribute little to the overall sedimentation in the German Bight, they rather impact the HMA sediments in a qualitative way (enhanced heavy metal contribution) than in a quantitative way (enhanced sedimentation). Indeed, measured sedimentation rates are rather constantly in the order of millimetres per year, which is in contrast to a previously assumed sudden increase in sedimentation rates to the order of centimetres per year in association with enhanced $\mathrm{Zn}$ and $\mathrm{Pb}$ inputs. Irrespective of the timing, the entire anthropogenic $\mathrm{Zn}$ and $\mathrm{Pb}$ inputs to the HMA are estimated to $12,000 \mathrm{t}$ of $\mathrm{Zn}$ and $4000 \mathrm{t}$ of $\mathrm{Pb}$.

Acknowledgements This research was funded by the German Research Foundation (DFG) through the International Research Training Group INTERCOAST - 'Integrated Coastal Zone and Shelf-Sea Research' (project no. GRK 1598). Further support was provided through the DFG-Research Center/Cluster of Excellence 'The Ocean in the Earth System' in Bremen. Sample material has been provided by the GeoB Core Repository and data have been partly acquired at the XRF Core Scanner Lab, both at the MARUM - Centre for Marine Environmental Sciences, University of Bremen, Germany. The data reported in this paper will be archived in Pangaea (www.pangaea.de).

Open Access This article is distributed under the terms of the Creative Commons Attribution 4.0 International License (http:// creativecommons.org/licenses/by/4.0/), which permits unrestricted use, distribution, and reproduction in any medium, provided you give appropriate credit to the original author(s) and the source, provide a link to the Creative Commons license, and indicate if changes were made.

\section{References}

Bard E (1998) Geochemical and geophysical implications of the radiocarbon calibration. Geochim Cosmochim Acta 62:2025-2038
Bartels C (1996) Mittelalterlicher und frühneuzeitlicher Bergbau im Harz und seine Einflüsse auf die Umwelt. Natur Wissen 83:483-491

Bindler R, Renberg I, Rydberg J, Andren T (2009) Widespread waterborne pollution in central Swedish lakes and the Baltic Sea from preindustrial mining and metallurgy. Environ Pollut 157:2132-2141

Birch GF (2017) Determination of sediment metal background concentrations and enrichment in marine environments - a critical review. Sci Total Environ 580:813-831

Boyle EA, Lee JM, Echegoyen Y, Noble A, Moos S, Carrasco G, Zhao N, Kayser R, Zhang J, Gamo T, Obata H, Norisuye K (2014) Anthropogenic lead emissions in the ocean: the evolving global experiment. Oceanography 27:69-75

Dominik J, Förstner U, Mangini A, Reineck HE (1978) ${ }^{210} \mathrm{~Pb}$ and ${ }^{137} \mathrm{Cs}$ chronology of heavy metal pollution in a sediment core from the German Bight (North Sea). Senckenberg Marit 10:213-227

FGG Elbe (2010) Elbebericht 2008-Ergebnisse des nationalen Überwachungsprogramms Elbe und der Bundesländer über den ökologischen Zustand der Elbe nach EG-WRRl sowie der Trendentwicklung von Stoffen und Schadstoffgruppen. Flussgemeinschaft Elbe, Hamburg

Figge K (1981) Karte der Sedimentverteilung in der Deutschen Bucht (No. 2900). Deutsches Hydrographisches Institut, Hamburg

Förstner U, Müller G (1973) Heavy metal accumulation in river sediments: a response top environmental pollution. Geoforum 14/:73

Förstner U, Reineck HE (1974) Die Anreicherung von Spurenelementen in den rezenten Sedimenten eines Profilkerns aus der Deutschen Bucht. Senckenberg Marit 6:175-184

Hamburg Port Authority (2015) Umgang mit Baggergut aus dem Hamburger. Teilbericht. Umlagerung von Baggergut nach Neßsand, Jahresbericht 2014. Hafen, Freie und Hansestadt Hamburg, Hamburg

Hebbeln D, Scheurle C, Lamy F (2003) Depositional history of the Helgoland Mud Area, German Bight, North Sea. Geo-Mar Lett 23:81-90

Heier-Nielsen S, Heinemeier J, Nielsen HL, Rud N (1995) Recent reservoir ages for Danish fjords and marine waters. Radiocarbon 37:875882

Hertweck G (1983) Das Schlickgebiet in der inneren Deutschen Bucht. Aufnahme mit dem Sedimentechographen. Senckenberg Marit 15: 219-249

Hinrichs J, Dellwig O, Brumsack HJ (2002) Lead in sediments and suspended particulate matter of the German Bight: natural versus anthropogenic origin. Appl Geochem 17:621-632

Irion G, Wunderlich F, Schwedhelm E (1987) Transport of clay minerals and anthropogenic compounds into the German Bight and the provenance of fine-grained sediments SE of Helgoland. J Geol Soc Lond 144:153-160

Jansen HF, van der Gaast SJ, Koster B, Vaars AJ (1998) CORTEX, shipboard XRF-scanner for element analyses in split sediment cores. Mar Geol 151:143-153

Kido Y, Koshikawa T, Tada R (2006) Rapid and quantitative major element analysis method for wet fine-grained sediments using an XRF microscanner. Quat Res 229:209-225

Lohse L, Malschaert JFP, Slomp CP, Helder W, van Raaphorst W (1995) Sediment-water fluxes of inorganic nitrogen compounds along the transport route of organic matter in the North Sea. Ophelia 41:173197

Martinez Cortizas A, Pontevedra-Pombal X, Novoa-Munos JC, GarciaRodeja E (1997) Four thousand years of atmospheric $\mathrm{Pb}, \mathrm{Cd}$ and $\mathrm{Zn}$ deposition recorded by the ombrotrophic peat bog of Penido Vello (Northwest Spain). Water Air Soil Pollut 100:387-403

Matschullat J, Ellminger F, Agdemir N, Cramer S, Ließmann W, Niehoff N (1997) Overbank sediment profiles - evidence of early mining and smelting activities in the Harz Mountains, Germany. Appl Geochem 12:105-114 
Mayer B (1995) Ein dreidimensionales, numerisches SchwebstoffTransportmodell mit Anwendung auf die Deutsche Bucht. Dissertation, Universität Hamburg

Monna F, Hamer K, Lévêque J, Sauer M (2000) Lead isotopes as a reliable marker of early mining and smelting in the northern Harz province (Lower Saxony, Germany). J Geochem Explor 68:201210

Ortlam D (1989) Geologie, Schwermetalle und Salzwasserfronten im Untergrund von Bremen und ihre Auswirkungen. Neues Jahrbuch für Geologie und Paläontologie Mh 8:489-512

OSPAR Commission (2000) Quality status report 2000, region IIgreater North Sea. OSPAR Commission, London $136+$ xiii pp

Ottley CJ, Harrison RM (1991) The atmospheric input flux of trace metals to the North Sea; a review and recommendations for research. Sci Total Environ 100:301-318

Pache T, Brockamp O, Clauer N (2008) Varied pathways of river-borne clay minerals in a near-shore marine region: a case study of sediments from the Elbe- and Weser rivers, and the SE North Sea. Estuar Coast Shelf Sci 78:563-575

Puls W, Pohlmann TH, Sündermann J (1997) Suspended particulate matter in the southern North Sea: application of a numerical model to extend NERC North sea project data interpretation. German Journal of Hydrography 49:307-327

Reimer PJ, Bard E, Bayliss A, Beck JW, Blackwell PG, Bronk Ramsey C, Buck CE, Cheng H, Edwards RL, Friedrich M, Grootes PM, Guilderson TP, Haflidason H, Hajdas I, Hatte C, Heaton TJ, Hoffmann DL, Hogg AG, Hughen KA, Kaiser KF, Kromer B, Manning SW, Niu M, Reimer RW, Richards DA, Scott EM, Southon JR, Staff RA, Turney CSM, van der Plicht J (2013) IntCal13 and Marine13 radiocarbon age calibration curves 0-50, 000 years cal BP. Radiocarbon 55:1869-1887

Reineck HE (1963) Sedimentgefüge im Bereich der südlichen Nordsee. Abh Senckenb Naturforsch Ges 505:1-138

Reineck HE, Gutmann WF, Hertweck G (1967) Das Schlickgebiet südlich Helgoland als Beispiel rezenter Schelfablagerungen. Senckenb Lethaea 48:219-275

Renberg I, Bindler R, Brännvall ML (2001) Using the historical atmospheric lead deposition record as a chronological marker in sediment deposits in Europe. Holocene 11:511-516

Rijnsdorp AD, Buys AM, Storbeck F, Visser EG (1998) Micro-scale distribution of beam trawl effort in the southern North Sea between 1993 and 1996 in relation to the trawling frequency of the sea bed and the impact on benthic organisms. J Mar Sci 55:403-419

Rotstigen $\mathrm{AB}$ (2009) Benthic foraminifera as a proxy for natural versus anthropogenic environmental change in the German Bight, North
Sea: a record over the last 1000 years. Master of Geosciences Thesis, University of Oslo, Oslo

Scheurle C, Hebbeln D (2003) Stable oxygen isotopes as recorders of salinity and river discharge in the German Bight, North Sea. GeoMar Lett 23:130-136

Scheurle C, Hebbeln D, Jones P (2005) An 800-year reconstruction of Elbe river discharge and German Bight Sea-surface salinity. Holocene 15:429-434

Schulz HD (1981) Die Kupferverhüttung auf Helgoland im Mittelalter. Offa 38:365-376

Serna A, Pätsch J, Dähnke K, Wiesner MG, Hass CH, Zeiler M, Hebbeln D, Emeis KC (2010) History of anthropogenic nitrogen input to the German Bight/SE North Sea as reflected by nitrogen isotopes in surface sediments, sediment cores and hindcast models. Cont Shelf Res 30:1626-1638

Stuiver M, Reimer PJ, Reimer RW (2017) CALIB 7.1 [WWWprogram] at https://calib.org Accessed 24 June 2016

Tjallingii R, Röhl U, Kölling M, Bickert T (2007) Influence of the water content on X-ray fluorescence core scanning measurements in soft marine sediments. Geochem Geophys Geosyst 8:1-12

Von Haugwitz W, Wong HK, Salge U (1988) The mud area southeast of Helgoland: a reflection seismic study. In: Mitteilungen aus dem Geologisch-Paläontologischen Institut der Universität, vol 65, Hamburg, pp 409-422

Weltje GJ, Tjallingii R (2008) Calibration of XRF core scanners for quantitative geochemical logging of sediment cores: theory and application. Earth Planet Sci Lett 274:423-438

Zaborska A (2014) Anthropogenic lead concentrations and sources in Baltic Sea sediments based on lead isotopic composition. Mar Pollut Bull 85:99-113

Zaborska A, Kosakowska A, Bełdowski J, Bełdowska M, Szubska M, Walkusz-Miotk J, Zak A, Ciechanowicz A, Wdowiak M (2017) The distribution of heavy metals and ${ }^{137} \mathrm{Cs}$ in the central part of the Polish maritime zone (Baltic Sea) - the area selected for wind farm acquisition. Estuar Coast Shelf Sci 198:471-481

Zeiler M, Schulz-Ohlberg J, Figge K (2000) Mobile sand deposits and shore-face sediment dynamics in the inner German Bight (North Sea). Mar Geol 170:363-380

Zillen L, Lenz C, Jilbart T (2012) Stable lead $(\mathrm{Pb})$ isotopes and concentrations - a useful independent dating tool for Baltic Sea sediments. Quat Geochronol 8:41-45

Publisher's note Springer Nature remains neutral with regard to jurisdictional claims in published maps and institutional affiliations. 